\title{
FACTORS AFFECTING TEACHERS' TECHNOLOGICAL PEDAGOGICAL AND CONTENT KNOWLEDGE (A SURVEY ON ECONOMICS TEACHER KNOWLEDGE)
}

\author{
Janah Sojanah*, Suwatno, Kodri, Amir Machmud \\ Universitas Pendidikan Indonesia, Indonesia \\ *e-mail: janahsojanah@upi.edu
}

\begin{abstract}
This study was conducted due to the lack of teachers' Technological Pedagogical and Content Knowledge (TPACK). It examined the effects of teaching experience, training, facilities and infrastructure, self-efficacy, as well as motivation on teachers' TPACK. The descriptive and explanatory methods with quantitative approaches were employed. The population of this study included 472 economics teachers in the Greater Bandung area, while the respondents were 217 economics teachers selected using the proportional probability sampling technique. The instrument used to collect the data was tried out to forty economics teachers. The instrument validity was measured using the CVR formula, and the instrument reliability was tested using construct reliability. The data were collected by means of questionnaires and then analyzed using descriptive analysis and Structural Equation Modeling (SEM). The results show that the teachers' experience, training, facilities and infrastructure, self-efficacy, as well as motivation are at a low level. Likewise, the teachers' TPACK seems to be low. Moreover, it is found that teaching experience, training, facilities and infrastructure, self-efficacy, as well as motivation have positive effects on teachers' TPACK.
\end{abstract}

Keywords: Technological Pedagogical and Content Knowledge (TPACK), economics teacher, Structural Equation Modeling.

\section{FAKTOR YANG MEMENGARUHI TECHNOLOGICAL PEDAGOGICAL DAN CONTENT KNOWLEDGE GURU (SURVEI PADA GURU EKONOMI)}

\begin{abstract}
Abstrak: Penelitian ini dilatarbelakangi oleh rendahnya Technological Pedagogical dan Content Knowledge (TPACK) guru. Penelitian ini bertujuan mengetahui pengaruh pengalaman mengajar, pelatihan, sarana dan prasarana, efikasi diri, serta motivasi terhadap TPACK guru. Penelitian ini menggunakan metode deskriptif dan ekplanasi dengan pendekatan kuantitatif. Populasi dalam penelitian ini adalah seluruh guru ekonomi se-Bandung Raya sebanyak 472 guru, sedangkan responden penelitian ini berjumlah 217 guru ekonomi diperoleh dengan teknik propobability sampling proportional. Uji coba instrumen dilakukan pada 40 guru ekonomi. Validitas dari instrumen diuji dengan formula CVR dan uji reliabilitas dengan Reliabilitas Konstruk. Data dikumpulkan dengan kuesioner. Data yang telah terkumpul dianalisis dengan menggunakan analisis deskriptif dan Structural Equation Modeling (SEM). Hasil penelitian menunjukkan pengalaman mengajar, pelatihan, sarana dan prasarana, efikasi diri, serta motivasi berada pada tingkatan yang cenderung rendah. Demikian pula dengan TPACK guru cenderung rendah. Selanjutnya, pengalaman mengajar, pelatihan, sarana dan prasarana, efikasi diri, serta motivasi berpengaruh positif terhadap TPACK guru.
\end{abstract}

\section{Kata Kunci: Technological Pedagogical and Content Knowledge (TPACK), guru ekonomi, Structural Equation Modeling.}

\section{INTRODUCTION}

The 21 st century is a time full of challenges in every dimension of human life, including education. The four skills that must be mastered by students in the 21 st century include: 1 ) core subject and 21st century themes; 2) learning and innovative skills; 3 ) information, media, and technological skills; and 4) life and career skills (Griffin \& Care, 2015; Larson \& Miller, 2011).
To add to the challenging demands of the $21 \mathrm{st}$ century for students, Indonesian students are faced with disappointing results of the 2018 Program for International Students Assessment (PISA) of an average score of 371 for reading, far below the average of the Organization for Economic Cooperation and Development (OECD) of 487. The average scores for mathematics and science were 379 and 389, respectively, also below the 
average OECD score of 487 (Wagner, Hahn, Schöps, Ihme, \& Köller, 2018).

The demands for students to have a good mastery of the 21 st century skills and the low results of PISA 2018 call for teachers as educational facilitators who play an important role in the success of students (Alawiyah, 2013; Darimi, 2015). However, teachers themselves are still faced with various problems, including low teacher standards and low mastery of content and media and technological literacy (Nofrion, Wijayanto, Wilis, \& Novio, 2018). Based on a survey by the United Nations Educational, Scientific, and Cultural Organization (UNESCO) on the quality of education in developing countries in the Asian-Pacific regions as reported in Global Education Monitoring (GEM) 2018, Indonesia ranked 10th out of 14 countries. As for the quality of educators, it ranked the lowest or 14th out of the 14 developing countries (Raharjo, 2012). In line with the results of the survey, the results of teacher competency tests in Indonesia in 2019 were still below the standard set by the government of 90.00 with a national average score of 54.05 (Sayekti, 2019).

Technological Pedagogical and Content Knowledge (TPACK) is a framework in teaching and learning combining three main components, namely technology, pedagogy, and content knowledge as requirements for teachers to teach effectively (Koehler \& Mishra, 2005). TPACK was first introduced by Koehler \& Mishra in 2005. They proposed the concept as a teacher framework in integrating ICT in learning. The concept of TPACK in technology learning was based on the Pedagogical Content Knowledge (PCK) model pioneered by Shulman (1986). TPACK consists of: 1) Content Knowledge (CK); 2) Technological Knowledge (TK); 3) Pedagogical Knowledge (PK); 4) Content Knowledge (CK); 5) Technological Pedagogical Knowledge (TPK); 6) Technological Content Knowledge (TCK); and 7) Pedagogical Content Knowledge (PCK) (Koehler \& Mishra, 2005; Archambault \& Crippen, 2009; Pamuk, Ergun, Cakir, Yilmaz, \& Ayas, 2013).

Some previous studies that examined the factors affecting teachers' TPACK include the theoretical research of Shulman (1986) from Stanford University. His theory explains that teaching experience, training, learning facilities and infrastructure (technology), self-efficacy, and motivation are the influential factors teachers' in pedagogical content knowledge. Ariani's (2015) research found that technology integration and self-efficacy were the factors affecting teachers' TPACK. Khine (2015) and Lee, Tsai, Chai, \& Koh (2014) investigated demographic characteristics (gender) and professional variables (length of teaching, level of education, and certification) as well as differences in school levels as factors affecting teachers' TPACK. TPACK is vital for teachers, among others, in creating learning media (Niess, 2011; Sholihah, Yuliati, \& Wartono, 2016), creating useful learning for students (Graham, 2011), mastery of learning strategies (Niess, van Zee, \& Gillow-Wiles, 2010; Niess, 2011), and using appropriate technology based on analysis of content characteristics. TPACK pedagogy requires a unique multi-interaction and synergy between content, pedagogy, and technology (Feladi \& Puspitasari, 2018; Koh, Chai, \& Tsai, 2010).

The originality of the present research lies in its attempt to identify and analyze factors that influence teachers' TPACK, namely teaching experience, training, facilities and infrastructure, self-efficacy, and motivation based on Shulman's (1986). It is a replication of and expansion of Ariani's research (2015) "Technology Integration and Self Efficacy Affecting Teachers' TPACK" and Khine (2015); Niess \& Gillow-Wiles (2019) research on gender and professional variables (length of teaching, level of education, and certification) as well as school level as factors influencing the TPACK of teachers. The difference between this research and the previous one lies in the research variables, research location, research time, research problems, and data analysis techniques. This research was conducted in Greater Bandung because of the availability of technological advice and infrastructure in learning that is already available but its use still needs to be improved.

Based on the background, in general the purpose of this study is to find factors affecting teachers' TPACK. More specifically, it aims to find: 1) the effect of teaching experience on teachers' TPACK; 2) the effect of training on teachers' TPACK; 3 ) the effect of facilities and infrastructure on teachers' TPACK; 4) the effect of self-efficacy on teachers' TPACK, and 5) the effect of motivation on teachers' TPACK. 


\section{METHODS}

The research employed descriptive and explanatory methods with quantitative approaches. It was carried out in the MGMP, a school cluster group of teachers teaching the same subject of Economics, of Greater Bandung area for 3 months, from December 2019 to February 2020. The population of this study was 472 teachers from 277 High Schools in Greater Bandung with the number of samples determined using the Slovin formula with an error of $5 \%$, and the proportional probability sampling technique obtained 217 respondents. Greater Bandung covers Bandung City, Bandung Regency, West Bandung Regency and Cimahi City.

In detail, the general description of respondents can be seen in Table 1 .

Table 1. Description of Research Respondents

\begin{tabular}{lcc}
\hline \multicolumn{3}{l}{ Respondents on Regency/City Region } \\
\hline No. Regency/City Region & Frequency & Percent \\
\hline 1. Bandung City & 88 & 40.55 \\
2. Bandung Regency & 86 & 39.63 \\
3. West Bandung Regency & 30 & 13.92 \\
4. Cimahi City & 13 & 5.90 \\
\hline Total & $\mathbf{2 1 7}$ & $\mathbf{1 0 0}$ \\
\hline
\end{tabular}

Respondents Based on Gender

\begin{tabular}{lcl}
\hline No. Gender & Frequency & Percent \\
\hline 1. Male & 82 & 37.79 \\
2. Female & 135 & 62.21 \\
\hline \multicolumn{1}{c}{ Total } & $\mathbf{2 1 7}$ & $\mathbf{1 0 0}$ \\
\hline
\end{tabular}

Respondents Based on Teaching Experience

\begin{tabular}{|c|c|c|}
\hline No. Teacher Experience & Frequency & Percent \\
\hline 1. $\leq 4$ Years & 14 & 5.20 \\
\hline 2. $5-7$ Years & 16 & 6.10 \\
\hline 3. 8-10 Years & 38 & 16.40 \\
\hline 4. 11-13 Years & 31 & 13.10 \\
\hline 5. 14-16 Years & 35 & 14.80 \\
\hline 6. 17-19 Years & 35 & 14.80 \\
\hline 7. 20-22 Years & 31 & 13.10 \\
\hline 8. $23-25$ Years & 10 & 3.60 \\
\hline 9. $>25$ years & 7 & 2.70 \\
\hline Total & 217 & 100 \\
\hline
\end{tabular}

Data were collected by distributing Likert questionnaires with a scale of 1-5 comprising of 90 statement items. The instrument test was conducted with 40 economics teachers.
The formula used for the validity test is CVR (Content Validity Ratio) and the reliability test is reliability construct. Based on the calculation of the critical value of the CVR validity test, it is known that of the 90 question items, all are in the range of .34 - 1 so that they are declared valid and can be used as instruments in this study. In addition, based on the results of the reliability test, it is known that the six variables, namely teaching experience, training, facilities and infrastructure, self-efficacy, motivation and teacher's TPACK can be said to be reliable. This is because the value of the construct reliability is below .50. Therefore all the constructs in this study can be used. The collected data were analyzed descriptively and with SEM. The instrument grid, the results of the validity and reliability tests are presented in Appendix 1, Appendix 2, and Appendix 3.

\section{RESULTS AND DISCUSSION Results}

The data obtained were analyzed descriptively in terms of teaching experience, training, infrastructure, self-efficacy, motivation and TPACK. For the data analysis of the questionnaire results, rating score 1 to 3 was categorized into low, while rating score 4 to 5 was into high. Subsequently, SEM analysis was performed to test the hypotheses.

\section{General Description of Teaching Experience}

Table 2 describes each dimension of teaching experience variable.

Table 2. Teaching Experience

\begin{tabular}{|c|c|c|c|}
\hline \multirow{2}{*}{ No. Dimension } & \multicolumn{2}{|c|}{$\begin{array}{c}\text { Percent } \\
\text { Frequency }\end{array}$} & \multirow{2}{*}{ Criteria } \\
\hline & Low & High & \\
\hline $\begin{array}{l}\text { 1. Length of } \\
\text { employment }\end{array}$ & 67.70 & 32.30 & $\begin{array}{l}\text { Tended to } \\
\text { be low }\end{array}$ \\
\hline $\begin{array}{l}\text { 2. Education and } \\
\text { training }\end{array}$ & 62.20 & 38.30 & $\begin{array}{l}\text { Tended to } \\
\text { be low }\end{array}$ \\
\hline
\end{tabular}

Based on the data presented in Table 2, it can be said that in general the teaching experience variable tended to be low. The dimension that contributed the lowest value was the length of employment with a percentage of $67.00 \%$, while the dimension with the highest contribution was education and training with $62.20 \%$. 


\section{General Description of Training}

Table 3 describes each of the dimensions of training variable.

Table 3. Training Variable

\begin{tabular}{|c|c|c|c|}
\hline \multirow{2}{*}{ No. Dimension } & \multicolumn{2}{|c|}{$\begin{array}{c}\text { Percent } \\
\text { Frequency }\end{array}$} & \multirow{2}{*}{ Criteria } \\
\hline & Low & High & \\
\hline 1. Knowledge & 54.95 & 45.05 & $\begin{array}{l}\text { Tended to } \\
\text { be low }\end{array}$ \\
\hline 2. Skills & 45.33 & 54.67 & $\begin{array}{l}\text { Tended to } \\
\text { be high }\end{array}$ \\
\hline 3. Attitude & 67.20 & 32.80 & $\begin{array}{l}\text { Tended to } \\
\text { be low }\end{array}$ \\
\hline 4. Continuity & 73.70 & 26.30 & $\begin{array}{l}\text { Tended to } \\
\text { be low }\end{array}$ \\
\hline
\end{tabular}

Based on the data displayed in Table 3, it can be inferred that in general the training variable tended to be low. The dimension that contributed the lowest value was continuity (73.70\%), while the dimension with the highest contribution was skill (54.67\%).

\section{General Description of Facilities and Infrastructure}

Table 4 presents descriptions of each dimension of the variable of facilities and infrastructure.

Table 4. Facilities and Infrastructure Variable

\begin{tabular}{|c|c|c|c|}
\hline \multirow{2}{*}{ No. Dimension } & \multicolumn{2}{|c|}{$\begin{array}{c}\text { Percent } \\
\text { Frequency }\end{array}$} & \multirow{2}{*}{ Criteria } \\
\hline & Low & High & \\
\hline 1. Planning & 63.90 & 36.10 & $\begin{array}{l}\text { Tended to } \\
\text { be low }\end{array}$ \\
\hline 2. Procurement & 57.33 & 42.67 & $\begin{array}{l}\text { Tended to } \\
\text { be low }\end{array}$ \\
\hline 3. Storage & 57.00 & 43.00 & $\begin{array}{l}\text { Tended to } \\
\text { be low }\end{array}$ \\
\hline 4. Inventory & 58.20 & 41.80 & $\begin{array}{l}\text { Tended to } \\
\text { be low }\end{array}$ \\
\hline $\begin{array}{l}\text { 5. Maintenance } \\
\text { and utilization }\end{array}$ & 60.81 & 39.9 & $\begin{array}{l}\text { Tended to } \\
\text { be low }\end{array}$ \\
\hline 6. Removal & 59.80 & 40.20 & $\begin{array}{l}\text { Tended to } \\
\text { be low }\end{array}$ \\
\hline 7. Monitoring & 57.05 & 42.95 & $\begin{array}{l}\text { Tended to } \\
\text { be low }\end{array}$ \\
\hline
\end{tabular}

Based on the data presented in Table 4, it can be said that generally the facilities and infrastructure variable tended to be low. The dimension with the lowest contribution was planning (63.90\%), while the dimension with the highest contribution was storage $(43.00 \%)$.

\section{General Description of Self-Efficacy}

To find the description of each dimension of the variable of self-efficacy, see Table 5.

Table 5. Self-Efficacy Variable

\begin{tabular}{|c|c|c|c|}
\hline \multirow{2}{*}{ No. Dimension } & \multicolumn{2}{|c|}{$\begin{array}{c}\text { Percent } \\
\text { Frequency }\end{array}$} & \multirow{2}{*}{ Criteria } \\
\hline & Low & High & \\
\hline $\begin{array}{l}\text { 1. Level of } \\
\text { difficulty }\end{array}$ & 56.17 & 43.83 & $\begin{array}{l}\text { Tended to } \\
\text { be low }\end{array}$ \\
\hline $\begin{array}{l}\text { 2. Breadth of } \\
\text { behavior }\end{array}$ & 52.03 & 47.97 & $\begin{array}{l}\text { Tended to } \\
\text { be low }\end{array}$ \\
\hline 3. Confidence & 51.15 & 48.85 & $\begin{array}{l}\text { Tended to } \\
\text { be low }\end{array}$ \\
\hline
\end{tabular}

Based on the results presented in Table 5 , it can be said that in general the self-efficacy variable tended to be low. The dimension with the lowest contribution was the level of difficulty $(56.17 \%)$, while the dimension with the highest contribution was confidence $(48.85 \%)$.

\section{General Description of Motivation}

To find descriptions of each dimension of motivation variable, see Table 6 .

Table 6. Motivation Variable

\begin{tabular}{|c|c|c|c|}
\hline \multirow{2}{*}{ No. Dimension } & \multicolumn{2}{|c|}{$\begin{array}{c}\text { Percent } \\
\text { Frequency }\end{array}$} & \multirow{2}{*}{ Criteria } \\
\hline & Low & High & \\
\hline $\begin{array}{l}\text { 1. Targeted } \\
\text { achievements }\end{array}$ & 62.50 & 37.50 & $\begin{array}{l}\text { Tended to } \\
\text { be low }\end{array}$ \\
\hline 2. Responsibility & 54.67 & 45.33 & $\begin{array}{l}\text { Tended to } \\
\text { be low }\end{array}$ \\
\hline 3. Independence & 60.00 & 40.00 & $\begin{array}{l}\text { Tended to } \\
\text { be low }\end{array}$ \\
\hline 4. Acknowledgement & 60.85 & 39.15 & $\begin{array}{l}\text { Tended to } \\
\text { be low }\end{array}$ \\
\hline 5. Self-improvement & 65.35 & 34.65 & $\begin{array}{l}\text { Tended to } \\
\text { be low }\end{array}$ \\
\hline
\end{tabular}

Based on the data presented in Table 6, a statement can be made that generally motivation variable tended to be low. The dimension with the lowest contribution was self-improvement (65.35\%), while the dimension with the highest contribution was responsibility (45.33\%). 
General Description of TPACK

To find descriptions of each dimension of the variable of TPACK, see Table 7.

Table 7. The Variable of TPACK

\begin{tabular}{|c|c|c|c|}
\hline \multirow[t]{2}{*}{ No. Dimension } & \multicolumn{2}{|c|}{$\begin{array}{c}\text { Percent } \\
\text { Frequency }\end{array}$} & \multirow[t]{2}{*}{ Criteria } \\
\hline & Low & High & \\
\hline $\begin{array}{l}\text { 1. Technological } \\
\text { Knowledge (TK) }\end{array}$ & 61.24 & 38.76 & $\begin{array}{l}\text { Tended to } \\
\text { be low }\end{array}$ \\
\hline $\begin{array}{l}\text { 2. Pedagogical } \\
\text { Knowledge (PK) }\end{array}$ & 61.88 & 38.12 & $\begin{array}{l}\text { Tended to } \\
\text { be low }\end{array}$ \\
\hline $\begin{array}{l}\text { 3. Content Knowledge } \\
\text { (CK) }\end{array}$ & 61.48 & 38.52 & $\begin{array}{l}\text { Tended to } \\
\text { be low }\end{array}$ \\
\hline $\begin{array}{l}\text { 4. Technological } \\
\text { Pedagogical } \\
\text { Knowledge (TPK) }\end{array}$ & 62.18 & 37.82 & $\begin{array}{l}\text { Tended to } \\
\text { be low }\end{array}$ \\
\hline $\begin{array}{l}\text { 5. Technological } \\
\text { Content Knowledge } \\
\text { (TCK) }\end{array}$ & 64.48 & 25.52 & $\begin{array}{l}\text { Tended to } \\
\text { be low }\end{array}$ \\
\hline $\begin{array}{l}\text { 6. Pedagogical Content } \\
\text { Knowledge (PCK) }\end{array}$ & 47.33 & 52.67 & $\begin{array}{l}\text { Tended to } \\
\text { be low }\end{array}$ \\
\hline $\begin{array}{l}\text { 7. Technological } \\
\text { Pedagogical Content } \\
\text { Knowledge (TPCK) }\end{array}$ & 61.52 & 38.48 & $\begin{array}{l}\text { Tended to } \\
\text { be low }\end{array}$ \\
\hline
\end{tabular}

The data presented in Table 7 show that in general the TPACK variable tended to be low. The dimension with the lowest contribution was TCK with a percentage of $64.48 \%$, while the dimension with the highest contribution was PCK with a percentage of $52.67 \%$.

The result of SEM using AMOS can be seen in Figure 1. Based on Figure 1, the following structural equation is obtained:

$$
\begin{aligned}
\mathrm{TPACK}= & .209 * \mathrm{TE}+.228 * \mathrm{~T}+.370 * \mathrm{FI}+ \\
& .321 * \mathrm{SE}+.275 \mathrm{M} ; \mathrm{R}^{2}=.377
\end{aligned}
$$

where, TPACK is Technological Pedagogical and Content Knowledge, TE is teaching experience, $\mathrm{T}$ refers to training, FI stand for facilities and infrastructure, SE represent the self-efficacy, M refers to motivation.

The equation (1) can be explained as follows: The relationship between teaching experience, training, facilities \& infrastructure, self-efficacy, and motivation and the teachers' TPACK had a positive direction. That is, low teaching experience, training, facilities \& infrastructure, self-efficacy, and motivation caused teachers to have low TPACK.

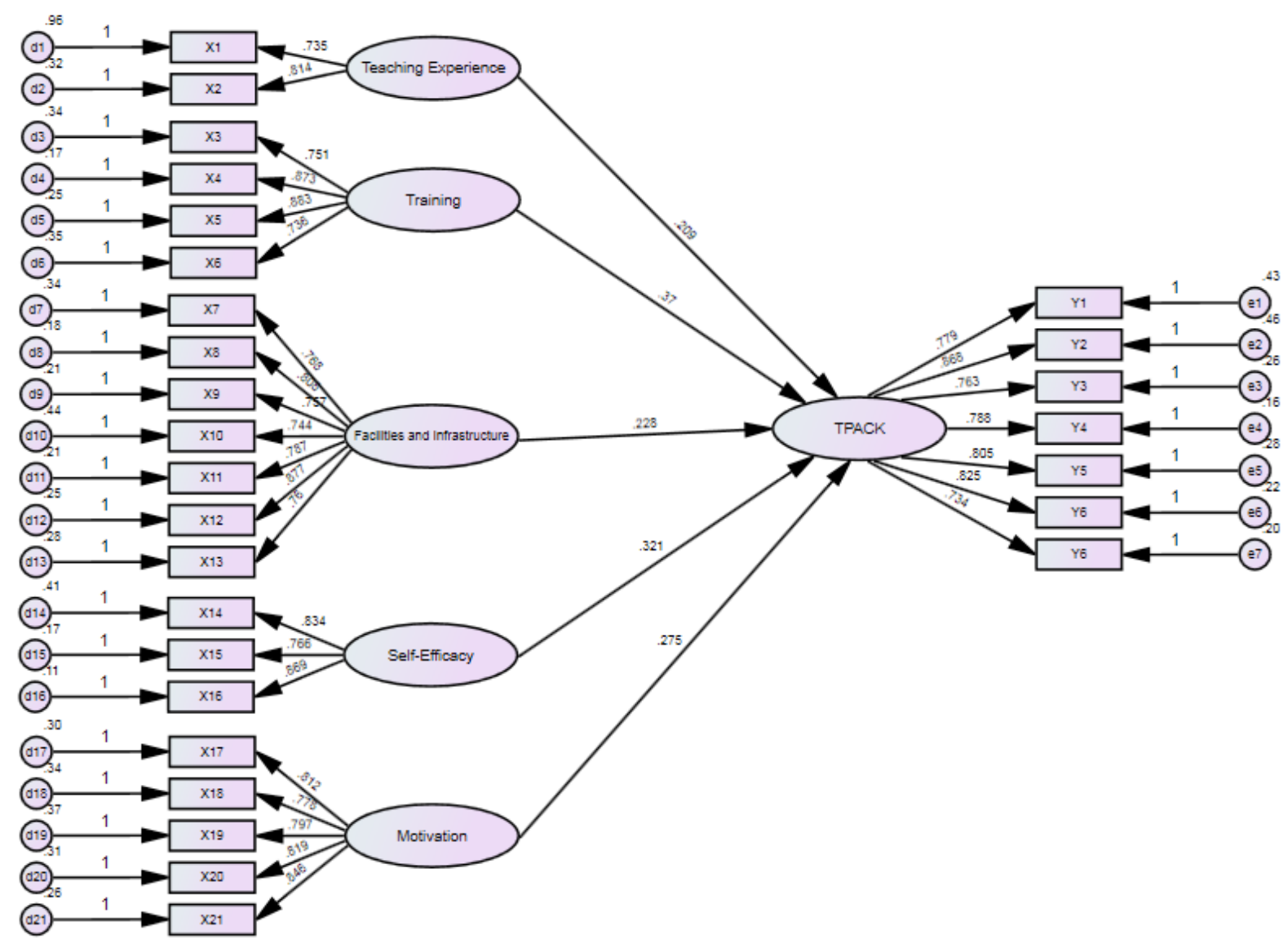

Figure 1. Structural Model Measurement (Standardized) 
The testing of the proposed hypotheses was done by calculating standardized regression coefficients. The results of the structural model parameter estimation are displayed in Table 8 and Table 9. Hypothesis testing was done by looking at the value of Critical Ratio (CR) at a significant level of $5 \%$. If the $\mathrm{CR}$ is significant with $p$-value $<.05$, the hypothesis proposed is significant. Conversely, if the value of CR is not significant with $p$-value) $>.005$, the hypothesis proposed is not significant.

Based on the parameter coefficient output shown in Table 8 and Table 9, the results of testing among constructs can be explained as follows:

The path coefficient (SRW) value in Table 8 is .098 (positive) $>0$, which indicates the level of the teachers' TPACK was affected by the level of teaching experience. The significant critical ratio of 2.214 with a probability of .024 was below .05 , meaning that the null hypothesis was rejected, and the alternative hypothesis was accepted. This means that teaching experience had a positive and significant effect on the teachers' TPACK. The effect of teaching experience on the teachers' TPACK is shown in Table 9.

The effect of teaching experience on the teachers' TPACK is shown in Table 9, where the $R^{2}$ value of .140 means $14.00 \%$ of the variations in the teachers' levels of TPACK can be explained by teaching experience. The remaining $86.00 \%$ was the effect of other variables not explained in this model.

Table 8 shows that the path coefficient
(SRW) is .228 (positive) $>0$, which indicates the level of the teachers' TPACK was affected by the level of training. The significant critical ratio of 1.965 with a probability of .049 was below .05 , meaning the null hypothesis could be rejected and the alternative hypothesis accepted. This means that training had a positive and significant effect on the teachers' TPACK. The effect of training on teachers' TPACK is shown in Table 9.

The effect of training on teachers' TPACK is shown in Table 9, where the $R^{2}$ value is .524 , which means $52.40 \%$ of the teachers' high or low TPACK could be explained by the training they received. The remaining $47.60 \%$ was the effect of other variables not explained in this model.

Table 8 shows the path coefficient (SRW) of .370 (positive) $>0$, which shows the level of teachers' TPACK was affected by the level of facilities and infrastructure. The significant critical ratio of 2.785 with a probability of .005 was below .05 , which means that the null hypothesis can be rejected, and the alternative hypothesis accepted. This means facilities and infrastructure had a positive and significant effect on the teachers' TPACK. The effect of facilities and infrastructure on teacher's TPACK is shown in Table 9.

The effect of facilities and infrastructure on the TPACK of teachers is shown in Table 12 , where the $R^{2}$ value of .245 means that $24.50 \%$ of variations in the teachers' TPACK can be explained by facilities and infrastructure. The remaining $75.50 \%$ was the effect of other variables not explained in this model.

Table 8. Results of Structural Model Parameter Estimation

\begin{tabular}{lccccc}
\hline Dimension & SR & SRW & SE & C.R & P \\
\hline Teacher's TPACK < - - Teaching experience & .193 & .098 & .087 & 2.214 & .024 \\
Teacher's TPACK < - - Training & .163 & .228 & .083 & 1.965 & .049 \\
Teacher's TPACK < - - Facilities and infrastructure & .176 & .370 & .063 & 2.785 & .005 \\
Teacher's TPACK < - - Self-efficacy & .151 & .321 & .061 & 2.481 & .013 \\
Teacher's TPACK < - - Motivation & .206 & .275 & .103 & 1.285 & .045 \\
\hline
\end{tabular}

Table 9. The Effect of Teaching Experience, Training, Facilities and Infrastructure, Self-Efficacy and Motivation on the Teachers' TPACK

\begin{tabular}{lc}
\hline Direct Effect & $\boldsymbol{R}^{2}$ \\
\hline Teaching experience on TPACK & .140 \\
Training on TPACK & .524 \\
Facilities and infrastructure on TPACK & .245 \\
Self-efficacy on TPACK & .251 \\
Motivation on TPACK & .483 \\
\hline
\end{tabular}


Table 8 indicates that the path coefficient (SRW) was .321 (positive) $>0$, which indicates the level of teachers' TPACK was affected by their level of self-efficacy. The significant critical ratio of 2.481 with a probability of .013 was below .05 , so the null hypothesis was rejected, and alternative hypothesis was accepted. This means that self-efficacy had a positive and significant effect on the teachers' TPACK. The effect of self-efficacy on teachers' TPACK is shown in Table 9.

The effect of self-efficacy on the teachers' TPACK is shown in Table 9, where the $R^{2}$ value of .251 means $25.10 \%$ of variations in the teachers' levels of TPACK can be explained by self-efficacy. The remaining $74.90 \%$ was the effect of other variables not explained in this model.

The path coefficient (SRW) as displayed in Table 8 is .275 (positive) $>0$, which indicates the level of teachers' TPACK was affected by the level of motivation. The significant critical ratio of 1.285 with a probability of .045 was below .05 , so the null hypothesis could be rejected, and the alternative hypothesis was accepted. This result means that motivation had a positive and significant effect on the teachers' TPACK. The effect of self-efficacy on the teachers' TPACK is shown in Table 9.

The effect of motivation on the teachers' TPACK is shown in Table 9, where the $R^{2}$ value of .483 means that $48.30 \%$ of variations in the teachers' level of TPACK can be explained by motivation. The remaining $51.70 \%$ was the effect of other variables not explained in this model.

\section{Discussion}

\section{The Effect of Teaching Experience on TPACK}

The results of this study indicate that low teaching experience had a positive effect on the teachers' low TPACK. The positive coefficient means that the lower the teaching experience, the lower the TPACK. This finding is in accordance with the theory put forward by Shulman (1986) that teaching experience will affect a teacher's pedagogical content knowledge.

This finding is also in line with the results of Niess \& Gillow-Wiles (2019) research reporting an influence of teaching experience on the TPACK of teachers. The finding further reinforces that of Park \& Oliver's (2008) research reporting a positive influence of teaching experience on teacher professionalism. Likewise, research conducted by Chai, Koh, Ho, \& Tsai (2012) reported teaching experience had a positive and significant effect on teacher professionalism. This shows the low teaching experience causes the low TPACK of teachers.

Teaching experience is the teacher's working period in carrying out his duties as an educator in a certain educational unit in accordance with an assignment letter from the authorized institution. Physical evidence of this component can be in the form of a legal decree or certificate from the competent authority (Spooner, Flowers, Lambert, \& Algozzine, 2010). Teaching experience affects teacher performance in carrying out tasks in order to achieve goals, as a teacher who is equipped with a lot of experience, it is possible to realize good enough achievement or performance and vice versa if there is not enough experience in carrying out his duties, he may experience failure. Previous or long experience as a teacher will make it easier to carry out activities and functions in accordance with their authority (Rice, 2010).

Teaching experience in general can improve work ability. So there are many variations of work and its objects, and the more intensive the work experience is obtained, the higher the work ability will be obtained by the teacher concerned. Thus, the more difficulties or obstacles faced, usually the faster the development of abilities and skills. Teaching experience is a major factor in TPACK of teachers. This is consistent with the research of Shulman (1986) and Park \& Oliver (2008) that "Teaching experience is the major source of TPACK",

\section{The Effect of Training on TPACK}

The results of this study indicate that low training had a positive effect on the low TPACK of teachers. The positive coefficient means that the lower the training, the lower the TPACK of teachers. This finding is in accordance with the theory put forward by Shulman (1986) which states that training will affect a teacher's pedagogical content knowledge.

This finding is also in line with the results of research by Koehler, Mishra, \& Yahya (2007) showing an influence of training on teachers' TPACK. This study also reinforces the research 
findings of Doering, Veletsianos, Scharber, \& Miller (2009) reporting a positive influence of training on teacher professionalism. Likewise, research conducted by Rienties, Brouwer, \& Lygo-Baker (2013) reported that training had a positive and significant effect on teacher performance. These results show low teaching experience causes low TPACK of teachers. Low level of training causes low TPACK of teachers. Training and education are every effort to improve the performance of their responsibilities, or a job that is related to their job (Vickerman, 2007).

Training is a series of individual activities in systematically increasing skills and knowledge so that they are able to have professional performance in their fields. Training is a learning process that allows employees to carry out their current work according to standards (Hoogveld, Paas, \& Jochems, 2005). Teacher education and training is very important to increase the ability and professionalism of teachers in carrying out their duties and functions. In line with this Koehler et al. (2007); Doering et al. (2009) "Training and Workshop is particularly successful in developing TPACK".

\section{The Effect of Facilities and Infrastructure on TPACK}

The results of this study indicate that low facilities and infrastructure had a positive effect on the low TPACK of the teachers. The positive coefficient means that the lower the facilities and infrastructure, the lower the TPACK of teachers. This finding is in accordance with the theory put forward by Shulman (1986) which states that training will affect teachers' pedagogical content knowledge.

This finding is also in line with the results of research by Dong, $\mathrm{Xu}$, Chai \& Zhai, (2019) which demonstrates that facilities and infrastructure had an effect on the TPACK of teachers. This study also strengthens the research findings of Yusuf, Baden, \& PrietoGodino (2014) showing a positive influence of facilities and infrastructure on teachers' teaching performance. Likewise, research conducted by Joo, Lim, \& Kim (2016) indicated that facilities and infrastructure had a positive and significant impact on teacher performance. These results show that the facilities and infrastructure cause teachers to have low TPACK.

Teachers need learning tools to support learning activities. The more complete and adequate the school learning facilities will make it easier for teachers to carry out their duties as educational personnel (Aminah, Waluya, Rochmad, Sukestiyarno, Wardono, \& Adiastuty, 2020). Likewise with the atmosphere during learning activities. Learning facilities must be developed in order to support the teaching and learning process (Xhafa, Caballé, Abraham, Daradoumis, \& Juan Perez, 2010).

The infrastructure in learning activities is very important for learning activities because teachers will be helped by the support of infrastructure facilities. Learning activities will also be more varied, interesting and meaningful. However, there is the obstacles related to learning facilities and infrastructure, teachers still experience difficulties with computer and internet media due to inadequate access and lack of knowledge and skills in using internet tools and computers (Bielaczyc, 2006).

Teachers should have a skills in using learning tools and media to facilitate the learning subjects. This is in line with (Shulman 1986; Harris, Mishra, \& Koehler, 2009) who reported that "Technology is effective for the development of TPACK in the area of technology education".

\section{The Effect of Self-Efficacy on TPACK}

The results of this study indicate that low efficacy positively affected low TPACK of teachers. The positive coefficient means that the lower the self-efficacy, the lower the TPACK of teachers. This finding is in accordance with the theory put forward by Shulman (1986) which states that self-efficacy will affect teachers' pedagogical content knowledge. This finding is also in line with the results of Milner \& Hoy' (2003) study reporting an effect of self-efficacy on the TPACK of teachers. This research also reinforces the findings of Abbitt (2011) that self-efficacy is very important for teachers in achieving learning goals. Likewise, research conducted by López-Vargas, Duarte-Suárez \& Ibáñez-Ibáñez (2017) showed self-efficacy had a positive and significant effect on teacher performance. These results show low selfefficacy causes teachers to have low TPACK.

Self-efficacy is a someone's belief of their abilities to do some form of control over one's own functions and events in the environment (Sitzmann \& Yeo, 2013). Self-efficacy is a self- 
perception of how well you can act in a certain situation, self-efficacy is related to the belief that you have the expected ability to act. Self-efficacy can be obtained, changed, increased or decreased (Day \& Allen, 2004). The factors that influence self-efficacy are experience of mastery, social modeling, social persuasion and physical and emotional conditions. In addition, the aspects of self-efficacy are level, strength, and generality (Erlina, Waluyo, Irawaty, Umar, \& Gayatri, 2019). Meanwhile, the functions of self-efficacy is to make it easier for individuals to obtain or achieve something in life, thus individuals needs to know the strategies are to increase selfefficacy which will be explained in the next sub (Bandura, 2000). Self-efficacy is very important for a teacher in achieving learning goals. In this regard, the results of the study Kind (2009); Park \& Oliver (2008).

\section{The Effect of Motivation on TPACK}

The results of this study indicate that low motivation had a positive effect on the low TPACK of teachers. The positive coefficient value means that the lower the motivation, the lower the TPACK of teachers. This finding is in accordance with the theory of Shulman (1986) stating that motivation will affect teachers' pedagogical content knowledge.

This finding also reinforces the findings of Goodnough \& Nolan's (2008) study which indicated that teachers with high motivation would tend to have higher TPACK than those who had low motivation. This study also reinforces the research findings of Handayani \& Rasyid (2015) demonstrating that motivation is very important for teachers in achieving learning goals. Likewise, research conducted by Bernaus \& Gardner (2008) reported that motivation had a positive and significant effect on teacher performance. These findings show that low motivation causes low TPACK of teachers.

Motivation is described as a process that occurs as a result of physical or physiological deficiency, or as a need that activates a behavior or as a drive that leads to the achievement of goals or incentives. Needs are closely related to deficiency, where the needs themselves are formed because of an imbalance in their physical or physiological condition. While encouragement, is related to the direction or orientation of a person to choose a certain behavior. This drive provides energy to achieve a goal (Luthans, 2001).

Motivation as an encouragement that is the driving force of mind and body to act and behave fulfilling certain goals in this case is the creation of a process of teaching and learning activities, as a form of a teacher's work to achieve job satisfaction. The motivational factor is a major factor in increasing teacher knowledge and performance in the classroom. In line with that, Shulman (1986); Goodnough \& Nolan (2008) explained that "Teachers with high motivation will tend to have higher Technological Pedagogical and Content Knowledge (TPACK) than those with low motivation.

\section{CONCLUSION}

The results show that teaching experience, training, facilities and infrastructure, selfefficacy, and motivation of the teachers under study were at a low level. Consequently, their TPACK tended to be low. Furthermore, teaching experience, training, facilities and infrastructure, self-efficacy, and motivation had positive effects on the TPACK of the teachers.

Based on the research findings, the authors provide suggestions that 1 ) teachers are expected to improve teaching experience in accordance with their field of expertise by making media in accordance with the to be taught content such as simple videos, ICT-based teaching materials, virtual classes and others; 2) Teachers are expected to increase training by following drafting training for media utilization programs and ICT learning models based on K13, following the Technical Guidance to draft substantive ICT learning media utilization programs for Economic Subjects and taking workshops ICT utilization in learning, held by related parties such as Pustekom Kemendikbud, Balai Teknologi \& Komunikasi Pendidikan (Tikomdik), Dinas Pendikan Jawa Barat, Microsoft Indonesia and others; 3) Teachers are expected to improve the management of facilities and infrastructure starting from planning, procurement, use \& utilization, maintenance, inventory supervision, and deletion, for those responsible for managing facilities and infrastructure must carry out tasks and their responsibilities; 4) Teachers are expected to improve self-efficacy by: a) take self-efficacy training; b) provide hands-on experience (mastery experience); c) maintaining 
emotional and bodily conditions and d) listen to verbal persuasion (advice, recommendation and suggestion); 5) Teachers are expected to increase motivation by: a) creating togetherness between teachers and school employees; b) create a sense of security in the school environment; c) accepting advice, recommendation and suggestion, and; d) respect the result of work of the teacher $\&$ give a reward to outstanding teachers.

\section{ACKNOWLEDGMENTS}

The authors would like to express their gratitude to the Chairman of Office of Education of West Java Province and the Musyawarah Guru Mata Pelajaran (MGMP) of Economics Teachers of Greater Bandung for their willingness to participate in the research.

\section{REFERENCES}

Abbitt, J. T. (2011). An investigation of the relationship between self-efficacy beliefs about technology integration and technological pedagogical content knowledge (TPACK) among preservice teachers. Journal of digital learning in teacher education, 27(4), 134-143. https://doi.org/10.1080/21532974.2011.1 0784670 .

Alawiyah, F. (2013). Peran guru dalam Kurikulum 2013. [The role of teachers in the 2013 Curriculum]. Journal of Aspirations, 4(1), 65-74. https://doi. org/10.46807/aspirasi.v4i1.480.

Aminah, N., Waluya, S. B., Rochmad, R., Sukestiyarno, S., Wardono, W., \& Adiastuty, N. (2020, April). Analysis of technology pedagogic content knowledge ability for junior high school teacher: Viewed TPACK framework. In Y. R. Hidayat, T. Suciaty, U. Syaripudin, A. Sustikarini, G. S. Brajadenta, I. Saleh, I. Indrayanti, I. S. W. Atmaja, F. Ferdiyanto, \& K. A. Rohman (Eds.). Proceedings of the International Conference on Agriculture, Social Sciences, Education, Technology and Health (ICASSETH 2019). Atlantis Press, pp. 257-260. https:// doi.org/10.2991/assehr.k.200402.060.

Archambault, L. \& Crippen, K. (2009).
Examining TPACK among K-12 online distance educators in the United States. Contemporary Issues in Technology and Teacher Education, 9(1), 71-88. https:// www.learntechlib.org/primary/p/29332/.

Ariani, D. N. (2015). Hubungan antara technological pedagogical content knowledge dengan technology integration self efficacy guru matematika di sekolah dasar. [Relationship between technological pedagogical content knowledge with technology integration self efficacy mathematics teachers in elementary schools]. Muallimuna: Jurnal Madrasah Ibtidaiyah, 1(1), 79-91. https://ojs.uniska-bjm.ac.id/index.php/ jurnalmuallimuna/article/view/277.

Bandura, A. (2000). Exercise of human agency through collective efficacy. Current Directions in Psychological Science, 9(3), 75-78. https://doi.org/10.1111/1467$\underline{8721.00064 .}$.

Bernaus, M., \& Gardner, R. C. (2008). Teacher motivation strategies, student perceptions, student motivation, and english achievement. The Modern Language Journal, 92(3), 387-401. https://doi. org/10.1111/j.1540-4781.2008.00753.x.

Bielaczyc, K. (2006). Designing social infrastructure: Critical issues in creating learning environments with technology. Journal of the Learning Sciences, 15(3), 301-329. https://doi.org/10.1207/ s15327809jls1503 1.

Chai, C. S., Koh, J. H. L., Ho, H. N. J., \& Tsai, C. C. (2012). Examining preservice teachers' perceived knowledge of TPACK and cyberwellness through structural equation modeling. Australasian Journal of Educational Technology, 28(Special issue, 6), 1000-1019. https://doi.org/10.14742/ ajet.807.

Darimi, I. (2015). Peningkatan kompetensi pedagogik guru PAI dalam pembelajaran. [Improvement of PAI teachers' pedagogical competencies in learning]. Jurnal Mudarrisuna: Media Kajian Pendidikan Agama Islam, 5(2), 309-324. 
https://jurnal.ar-raniry.ac.id/index.php/ mudarrisuna/article/view/630.

Day, R., \& Allen, T. D. (2004). The relationship between career motivation and selfefficacy with protégé career success. Journal of Vocational Behavior, 64(1), 72-91. https://doi.org/10.1016/S00018791(03)00036-8.

Doering, A., Veletsianos, G., Scharber, C., \& Miller, C. (2009). Using the technological, pedagogical and content knowledge framework in professional development. Journal of Educational Computing Research, 41(3), 319-346. https://doi. org/10.2190/EC.41.3.d.

Dong, Y., Xu, C., Chai, C. S., \& Zhai, X. (2019). Exploring the structural relationshipamong teachers' technostress, technological pedagogical content knowledge (TPACK), computer self-efficacy and school support. The Asia-Pacific Education Researcher, 29, 147-157. https://doi.org/10.1007/ s40299-019-00461-5.

Erlina, L., Waluyo, A., Irawaty, D., Umar, J., \& Gayatri, D. (2019). Instrument development and validation: Assessment of self efficacy for mobilization. Enfermería Clínica, 29(Supplement 2), 384-389. https://doi.org/10.1016/j. enfcli.2019.04.048.

Feladi, V., \& Puspitasari, H. (2018). Analisis profil TPACK guru TIK SMA di Kecamatan Pontianak Kota. [Analysis of TPACK profile of high school ICT teachers in Pontianak City District]. Jurnal Edukasi dan Penelitian Informatika, 4(2), 204-210. https://doi.org/10.26418/ ip.v4i2.29616.

Graham, C. R. (2011). Theoretical considerations for understanding technological pedagogical content knowledge (TPACK). Computers \& Education, 57(3), 1953-1960. $\quad$ https://doi.org/10.1016/j. compedu.2011.04.010.

Goodnough, K., \& Nolan, B. (2008). Engaging elementary teachers' pedagogical content knowledge: Adopting problem-based learning in the context of science teaching and learning. Canadian Journal of Science, Mathematics, and Technology Education, 8(3), 197-216. https://doi. org/10.1080/14926150802315130.

Griffin, P., \& Care, E. (2015). The ATC21S method. In E. Care, P. Griffin, \& M. Wilson (Eds.). Assessment and teaching of 21st century skills: Research and application. Springer International Publishing, $\mathrm{pp}$. 3-33. https://doi.org/10.1007/978-94017-9395-7 1.

Handayani, T., \& Rasyid, A. A. (2015). Pengaruh kepemimpinan kepala sekolah, motivasi guru, dan budaya organisasi terhadap kinerja guru SMA Negeri Wonosobo. [The influence of school principal leadership, teacher motivation, and organizational culture on the performance of Wonosobo high school teachers]. Jurnal Akuntabilitas Manajemen Pendidikan, 3(2), 264-277. https://doi.org/10.21831/amp.v3i2.6342.

Harris, J., Mishra, P., \& Koehler, M. (2009). Teachers' technological pedagogical content knowledge and learning activity types. Journal of Research on Technology in Education, 41(4), 393-416. https://doi. org/10.1080/15391523.2009.10782536.

Hoogveld, A. W., Paas, F., \& Jochems, W. M. (2005). Training higher education teachers for instructional design of competencybased education: Product-oriented versus process-oriented worked examples. Teaching and Teacher Education, 21(3), 287-297. https://doi.org/10.1016/j. tate.2005.01.002.

Joo, Y. J., Lim, K. Y., \& Kim, N. H. (2016). The effects of secondary teachers' technostress on the intention to use technology in South Korea. Computers \& Education, 95, 114-122. https://doi.org/10.1016/j. compedu.2015.12.004.

Khine, M. S. (2015). Technology-enhanced learning and TPACK. In M. S. Khine (Ed.). New directions in technological pedagogical content knowledge research: Multiple perspectives. Charlotte, NC: Information Age Publishing, pp. 3-8. 
https://doi.org/10.1007/s10639-0169507-8.

Kind, V. (2009). Pedagogical content knowledge in science education: Perspectives and potential for progress. Studies in Science Education, 45(2), 169-204. https://doi. org/10.1080/03057260903142285.

Koehler, M. J., \& Mishra, P. (2005). What happens when teachers design educational technology? The development of technological pedagogical content knowledge. Journal of educational computing research, 32(2), 131-152. https://doi.org/10.2190/0EW7-01WBBKHL-QDYV.

Koehler, M. J., Mishra, P., \& Yahya, K. (2007). Tracing the development of teacher knowledge in a design seminar: Integrating content, pedagogy and technology. Computers \& Education, 49(3), 740-762. https://doi.org/10.1016/j. compedu.2005.11.012.

Koh, J. H. L., Chai, C. S., \& Tsai, C. C. (2010). Examining the technological pedagogical content knowledge of Singapore preservice teachers with a large-scale survey. Journal of Computer Assisted Learning, 26(6), 563-573. https://doi.org/10.1111/ j.1365-2729.2010.00372.x.

Larson, L. C., \& Miller, T. N. (2011). 21st century skills: Prepare students for the future. Kappa Delta Pi Record, 47(3), 121-123. https://doi.org/10.1080/002289 58.2011.10516575.

Lee, K., Tsai, P. S., Chai, C. S., \& Koh, J. H. L. (2014). Students' perceptions of self-directed learning and collaborative learning with and without technology. Journal of Computer Assisted Learning, 30(5), 425-437. https://doi.org/10.1111/ jcal.12055.

López-Vargas, O., Duarte-Suárez, L., \& IbáñezIbáñez, J. (2017). Teacher's computer self-efficacy and its relationship with cognitive style and TPACK. Improving Schools, 20(3), 264-277. https://doi. org/10.1177/1365480217704263.
Stajkovic, A. D., \& Luthans, F. (2001). Differential effects of incentive motivators on work performance. Academy of Management Journal, 44(3), 580-590. https://doi.org/10.5465/3069372.

Milner, H. R., \& Hoy, A. W. (2003). A case study of an African American teacher's selfefficacy, stereotype threat, and persistence. Teaching and teacher Education, 19(2), 263-276. https://doi.org/10.1016/S0742051X(02)00099-9.

Niess, M. L., van Zee, E. H., \& Gillow-Wiles, H. (2010). Knowledge growth in teaching mathematics/science with spreadsheets: Moving PCK to TPACK through online professional development. Journal of Digital Learning in Teacher Education, 27(2), 42-52. https://doi.org/10.1080/215 32974.2010.10784657.

Niess, M. L., \& Gillow-Wiles, H. (2019). Online instructional strategies for enhancing teachers' TPACK: Experiences, discourse, and critical reflection. In M. L. Niess, H. Gillow-Wiles, \& C. Angeli (Eds.). Handbook of research on TPACK in the digital age. Hershey, PA: IGI Global, pp. 257-278.

Niess, M. L. (2011). Investigating TPACK: Knowledge growth in teaching with technology. Journal of Educational Computing Research, 44(3), 299-317. https://doi.org/10.2190/EC.44.3.c.

Nofrion, N., Wijayanto, B., Wilis, R., \& Novio, R. (2018). Analisis technological pedagogical and content knowledge (TPACK) guru geografi di Kabupaten Solok, Sumatera Barat. Jurnal geografi, 10(2), 105-116. https://doi.org/10.24114/ jg.v10i2.9070.

Pamuk, S., Ergun, M., Cakir, R., Yilmaz, H. B., \& Ayas, C. (2013). Exploring relationships among TPACK components and development of the TPACK instrument. Education and Information Technologies, 20(2), 241-263. https://doi.org/10.1007/ s10639-013-9278-4.

Park, S., \& Oliver, J. S. (2008). Revisiting 
the conceptualisation of pedagogical content knowledge (PCK): PCK as a conceptual tool to understand teachers as professionals. Research in Science Education, 38(3), 261-284. https://doi. org/10.1007/s11165-007-9049-6.

Raharjo, S. B. (2012). Evaluasi trend kualitas pendidikan di Indonesia. [Evaluation of quality trends in education in Indonesia]. Jurnal Penelitian dan Evaluasi Pendidikan, 16(2), 511-532. https://doi. org/10.21831/pep.v16i2.1129.

Rice, J. K. (2010). The impact of teacher experience examining the evidence and policy implications. National Center for Analysis of Longitudinal Data in Education Research Working Paper, Brief 11 (August). https://caldercenter.org.

Rienties, B., Brouwer, N., \& Lygo-Baker, S. (2013). The effects of online professional development on higher education teachers' beliefs and intentions towards learning facilitation and technology. Teaching and Teacher Education, 29, 122-131. https:// doi.org/10.1016/j.tate.2012.09.002.

Sayekti, W. N. L. (2019). Kontribusi uji kompetensi guru, motivasi berprestasi, dan pengalaman mengajar terhadap kompetensi profesional guru. [The contribution of teacher competency test, achievement motivation, and teaching experience to teacher professional competence]. Media Manajemen Pendidikan, 1(3), 123-130. https://jurnal. ustjogja.ac.id/index.php/mmp/article/ view/4071.

Sholihah, M.A., Yuliati,L., \& Wartono, W.(2016). Peranan TPACK terhadap kemampuan menyusun perangkat pembelajaran calon guru fisika dalam pembelajaran POSTPACK. [Role of TPACK on the ability to arrange the learning tools of prospective physics teachers in POST-PACK learning]. Jurnal Pendidikan: Teori, Penelitian, dan Pengembangan, 1(2), 144-153. http:// journal.um.ac.id/index.php/jptpp/article/ view/6115.

Shulman, L. S. (1986). Those who understand:
Knowledgegrowthinteaching. Educational researcher, 15(2), 4-14. https://doi. org/10.3102/0013189X015002004.

Sitzmann, T., \& Yeo, G. (2013). A meta-analytic investigation of the within-person selfefficacy domain: Is self-efficacy a product of past performance or a driver of future performance? Personnel Psychology, 66(3), 531-568. https://doi.org/10.1111/ peps. 12035 .

Spooner, M., Flowers, C., Lambert, R., \& Algozzine, B. (2008). Is more really better? Examining perceived benefits of an extended student teaching experience. The Clearing House: A Journal of Educational Strategies, Issues and Ideas, 81(6), 263-270. https://doi.org/10.3200/ TCHS.81.6.263-270.

Vickerman,P.(2007). Training physical education teachers to include children with special educational needs: Perspectives from physical education initial teacher training providers. European Physical Education Review, 13(3), 385-402. https://doi. org/10.1177/1356336X07083706.

Wagner, H., Hahn, I., Schöps, K., Ihme, J. M., \& Köller, O. (2018). Are the tests scores of the Programme for International Student Assessment (PISA) and the National Educational Panel Study (NEPS) science tests comparable? An assessment of test equivalence in German Schools. Studies in Educational Evaluation, 59, 278-287. https://doi.org/10.1016/j. stueduc.2018.09.002.

Xhafa, F., Caballé, S., Abraham, A., Daradoumis, T., \& Juan Perez, A. A. (Eds.). (2010). Computational intelligence for technology enhanced learning. Heidelberg: SpringerVerlag. https://doi.org/10.1007/978-3642-11224-9.

Yusuf, S., Baden, T., \& Prieto-Godino, L. L. (2014). Bridging the Gap: establishing the necessary infrastructure and knowledge for teaching and research in neuroscience in Africa. Metabolic Brain Disease, 29(2), 217-220. https://doi.org/10.1007/s11011013-9443-x. 
Appendix 1. The Instruments Grid of Factors Affecting TPACK

\begin{tabular}{|c|c|c|c|}
\hline Variable & Dimensions & Statement Number & $\begin{array}{l}\text { Number } \\
\text { of Items }\end{array}$ \\
\hline \multirow{2}{*}{$\begin{array}{l}\text { Teaching } \\
\text { experience }\end{array}$} & Length of employment & 1,2 & 2 \\
\hline & Education and training & 3 & 1 \\
\hline \multirow[t]{4}{*}{ Training } & Knowledge & 4,5 & 2 \\
\hline & Skills & $6,7,8$ & 3 \\
\hline & Attitude & 9,10 & 2 \\
\hline & Continuity & 11,12 & 2 \\
\hline \multirow{7}{*}{$\begin{array}{l}\text { Facilities and } \\
\text { infrastructure }\end{array}$} & Planning & 13,14 & 2 \\
\hline & Procurement & $15,16,17$ & 3 \\
\hline & Storage & 18 & 1 \\
\hline & Inventory & 19,20 & 2 \\
\hline & Maintenance and utilization & $21,22,23,24,25,26$ & 6 \\
\hline & Removal & 27,28 & 2 \\
\hline & Monitoring & 29,30 & 2 \\
\hline \multirow[t]{3}{*}{ Sel-efficacy } & Level/magnitude & $31,32,33$ & 3 \\
\hline & Generality & $34,35,36,37,38,39,40$ & 7 \\
\hline & Strength & $41,42,43,44,45,46,47,48$ & 8 \\
\hline \multirow[t]{8}{*}{ Motivation } & Targeted achievements & 49,50 & 2 \\
\hline & Responsibility & $51,52,53$ & 3 \\
\hline & Independence & 54,55 & 2 \\
\hline & Acknowledgement & 56,57 & 2 \\
\hline & Self-improvement & 58,59 & 2 \\
\hline & $\mathrm{TK}$ & $60,61,62,63,64$ & 5 \\
\hline & $\mathrm{PK}$ & $65,66,67,68,69$ & 5 \\
\hline & $\mathrm{CK}$ & $70,71,72,73$ & 4 \\
\hline \multirow[t]{4}{*}{ TPACK } & TPK & $74,75,76,77$ & 4 \\
\hline & TCK & $78,79,80,81$ & 4 \\
\hline & PCK & $82,83,84,85$ & 4 \\
\hline & TPCK & $86,87,88,89,90$ & 5 \\
\hline \multicolumn{3}{|c|}{ Total } & 90 \\
\hline
\end{tabular}


Appendix 2. Validity Test of Research Instruments

\begin{tabular}{|c|c|c|c|c|c|}
\hline $\begin{array}{l}\text { Number } \\
\text { of Items }\end{array}$ & CVR & Description & $\begin{array}{l}\text { Number } \\
\text { of Items }\end{array}$ & CVR & Description \\
\hline 1 & .442 & Corresponding & 46 & .523 & Corresponding \\
\hline 2 & .610 & Corresponding & 47 & .641 & Very compatible \\
\hline 3 & .558 & Corresponding & 48 & .872 & Very compatible \\
\hline 4 & .734 & Very compatible & 49 & .730 & Very compatible \\
\hline 5 & .578 & Corresponding & 50 & .681 & Very compatible \\
\hline 6 & .657 & Corresponding & 51 & .525 & Corresponding \\
\hline 7 & .868 & Very compatible & 52 & .410 & Corresponding \\
\hline 8 & .643 & Corresponding & 53 & .487 & Corresponding \\
\hline 9 & .663 & Corresponding & 54 & .730 & Very compatible \\
\hline 10 & .424 & Corresponding & 55 & .675 & Corresponding \\
\hline 11 & .545 & Corresponding & 56 & .730 & Very compatible \\
\hline 12 & .601 & Corresponding & 57 & .520 & Corresponding \\
\hline 13 & .576 & Corresponding & 58 & .547 & Corresponding \\
\hline 14 & .346 & Corresponding & 59 & .717 & Corresponding \\
\hline 15 & .677 & Very compatible & 60 & .730 & Very compatible \\
\hline 16 & .467 & Corresponding & 61 & .576 & Corresponding \\
\hline 17 & .589 & Corresponding & 62 & .426 & Corresponding \\
\hline 18 & .647 & Corresponding & 63 & .677 & Corresponding \\
\hline 19 & .700 & Very compatible & 64 & .467 & Corresponding \\
\hline 20 & .424 & Corresponding & 65 & .589 & Corresponding \\
\hline 21 & .698 & Very compatible & 66 & .647 & Corresponding \\
\hline 22 & .618 & Corresponding & 67 & .700 & Very compatible \\
\hline 23 & .426 & Corresponding & 68 & .824 & Very compatible \\
\hline 24 & .580 & Corresponding & 69 & .698 & Very compatible \\
\hline 25 & .661 & Corresponding & 70 & .618 & Corresponding \\
\hline 26 & .880 & Very compatible & 71 & .426 & Corresponding \\
\hline 27 & .470 & Corresponding & 72 & .480 & Corresponding \\
\hline 28 & .580 & Corresponding & 73 & .661 & Corresponding \\
\hline 29 & .530 & Corresponding & 74 & .885 & Very compatible \\
\hline 30 & .790 & Very compatible & 75 & .478 & Corresponding \\
\hline 31 & .440 & Corresponding & 76 & .580 & Corresponding \\
\hline 32 & .680 & Very compatible & 77 & .535 & Corresponding \\
\hline 33 & .690 & Very compatible & 78 & .793 & Very compatible \\
\hline 34 & .540 & Corresponding & 79 & .442 & Corresponding \\
\hline 35 & .760 & Very compatible & 80 & .651 & Corresponding \\
\hline 36 & .460 & Corresponding & 81 & .661 & Corresponding \\
\hline 37 & .880 & Very compatible & 82 & .540 & Corresponding \\
\hline 38 & .470 & Corresponding & 83 & .760 & Very compatible \\
\hline 39 & .380 & Corresponding & 84 & .461 & Corresponding \\
\hline 40 & .530 & Corresponding & 85 & .885 & Very compatible \\
\hline 41 & .791 & Very compatible & 86 & .883 & Very compatible \\
\hline 42 & .443 & Corresponding & 87 & .471 & Corresponding \\
\hline 43 & .651 & Corresponding & 88 & .783 & Corresponding \\
\hline 44 & .664 & Corresponding & 89 & .537 & Corresponding \\
\hline 45 & .546 & Corresponding & 90 & .880 & Very compatible \\
\hline
\end{tabular}


Appendix 3. The Results of Reliability Test

\begin{tabular}{llc}
\hline Variable & RC & Description \\
\hline Teacher experience & .308 & Reliable \\
Training & .301 & Reliable \\
Facilities and infrastructure & .336 & Reliable \\
Self efficacy & .420 & Reliable \\
Motivation & .388 & Reliable \\
\hline TPACK & .361 & Reliable \\
\hline
\end{tabular}

